\title{
Aiming at Sustainable Innovation in Teacher Education - from Theory to Practice
}

\author{
Márta TURCSÁNYI-SZABÓ \\ Eötvös Lorand University, Faculty of Informatics, Dept. Media \& Educational Informatics \\ Pázmány Péter sétány 1/c., 1117 Budapest, Hungary \\ e-mail: tszmarta@inf.elte.hu
}

Received: December 2011

\begin{abstract}
The paper composes a framework for learning design, using Web 2.0 technologies in teacher training, transferring the advancement in technology to become an affordance in the teaching/learning process, based on Bloom's Extended Digital Taxonomy in order to enhance the Technological Pedagogical and Content Knowledge of teachers. As a case study, it shows how ELTE University tries to develop sustainable innovation of competencies in digital literacy and modern teaching/learning methodologies directly among the teaching staff in teacher training and student/future teachers as well as indirectly within public education in order to transfer innovation there. The complex aims of a specific course Educational Technology are described with detailed explanation of the methodology used in attaining the prescribed aims, giving links to the concrete tools and resources used. The description of course requirements are tagged with features of the nature of the learning design as being transmissive, dialogic, constructionist and co-constructive, illustrating how each element contributes to the adaptation of theory into practice. The role of a newly established T@T Mentoring Network is explained, which presumes sustainability for innovation within teacher training and the network of in-service and practicing teachers.
\end{abstract}

Keywords: teacher training, competencies, innovation, sustainability, networking.

\section{Introduction}

The 21st century is dedicated to bring up a knowledge-based society in which required competencies strive to follow the extremely fast development of tools that are needed for enhanced work and Life Long Learning. But, the structure of teacher education is not suitable to handle the extent of changes progressing in our daily lives influencing the next generation of learners. Thus, there needs to be a sustainable flow of innovation continuously shaping public education in order to bring up a generation that can stand up to requirements within the future workforce.

According to the Merriam Webster dictionary, innovation is merely "the introduction of something new" and Wikipedia adds very wisely, that "the central meaning of innovation relates to renewal or improvement, with novelty being a consequence of this improvement". One can read a lot of articles on innovation, which suggests a set of tools that are considered to be innovative and thus makes believe that the use of which would result in innovation. Web 2.0 tools are referred to as such, but very often even the description of 
this set of tools is unclear to the public as well as teachers who are supposed to achieve innovation by using them in their daily routines. Articles a few years ago suggested that Web 2.0 technologies would soon replace Virtual Learning Environments (Brown, 2008) and some trends even suggested that FaceBook might be the ultimate Learning Management System soon (Walsh, 2011).

Take it or not, a new generation has emerged from those who grew up surrounded by digital tools in their everyday environment and some claim that this has led to young people developing a natural aptitude and high skill levels in relation to new technologies. Older people - naturally most of the teachers involved in education - grew up in an analogue world and thus lag behind, as being immigrants to this new world and never likely to reach the level of skills and fluency developed naturally by those who have grown up with new digital technologies (Tapscott, 2009). While recently the previous allegations - that the Net generation is consequently a fluent technology user - are being debated (Corrin et al., 2010). It is quite evident - due to the aging of teaching workforce (OECD, 2009 ) - that the later might well be true. No matter the achievements, the young generation is surrounded by ever growing use of technology in the everydays and is distracted by flashy technology out of school. But, for years now, the least progressive institution is considered to be the school itself, having great difficulties with changing educational paradigms (Robinson, 2011).

\section{Buzz Words - How to Adapt Them?}

Web 2.0 has been a buzz word for some time now, with lots of writings including tables to illustrate the differences between Web 1.0, 2.0. and 3.0, some even being very good descriptions (Anderson, 2007; Tiropanis et al., 2009), yet not making it much easier for students with or without adequate ICT background to understand the essence of the differences. To ease understanding and allow a transferable frame to emerge in the heads of student/future teachers (those studying at university to become teachers), a simplified model was introduced by the author, which allowed direct transfer of technological innovation into the renewing learning model itself.

Innovation in Web technologies transferred the process of "push"-ing information defined by the owner (unidirectional in Web 1.0) to building information with the users (bidirectional in Web 2.0), resulting in the "pull" on necessary information by the user (a third element in Web 3.0) facilitated by Artificial Intelligence (AI) for personalization to users' needs (Fig. 1.). Technology thus allows users to upgrade themselves from being a passive information consumer (to whom information is pushed) into an active contributor of chunks of information (crowdsourcing information). And due to new elements of AI, which can determine the type of information a user is interested at a specific instance (personalized information facilitated by even locative services on mobile technology) the users can gather selected feeds of information sources that are needed to complete a specific task.

The innovation of Web technologies must transform the teaching process into a student centered learning process, where the teacher generated knowledge transfer (unidirec- 


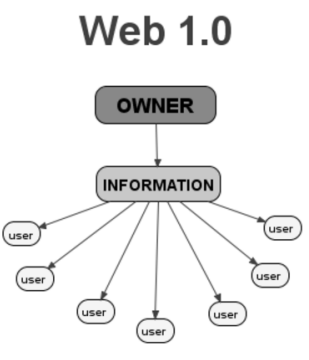

Push Information

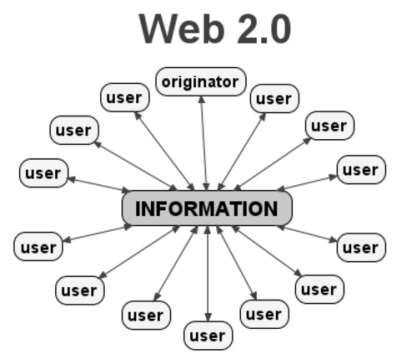

Crowdsourcing

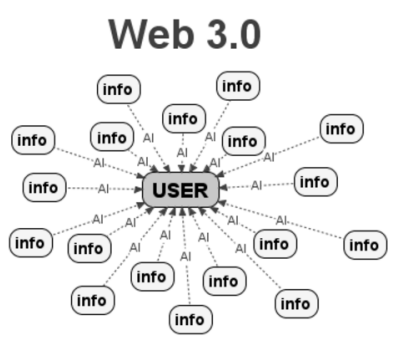

Pull Personalized Information

Fig. 1. Mindmap showing change of significance of actors and flow in Web technology.
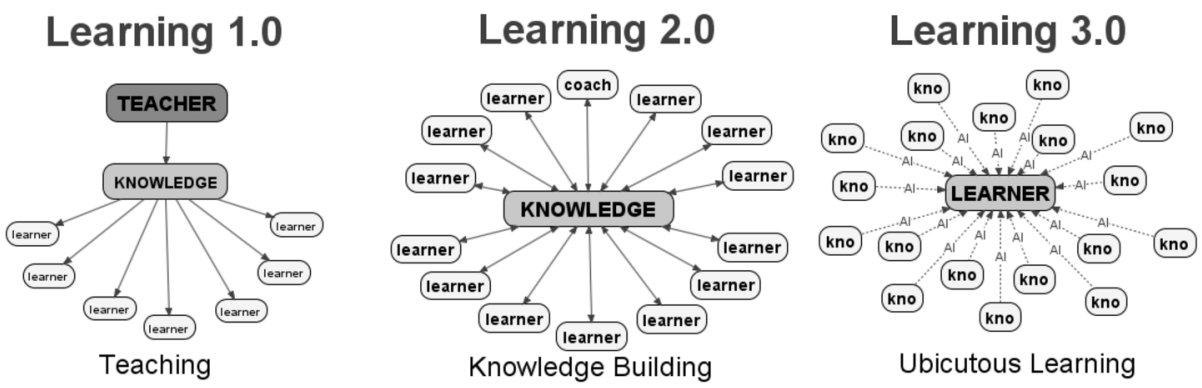

Fig. 2. Mindmap showing change of significance of actors and flow in Learning.

tional in Learning 1.0) converts into a collaborative knowledge building process (bidirectional in Learning 2.0), resulting in ubiquitous learning (using a third element in Learning 3.0) facilitated by AI for personalization to learners' needs (Fig. 2). Technology should thus allow learners to upgrade themselves from being a passive knowledge consumer (to whom knowledge is pushed) into an active contributor in a social constructionist process (knowledge building). And due to new elements of artificial intelligence, which can determine the type of knowledge a learner is in need at a specific time and place (ubicutously - anywhere, anytime) the user can gather selected feeds of knowledge sources in order to complete a specific task.

Thus, buzz words should be cropped to produce a model that can be understood and applied to make sure that theory goes into practice in teacher training in order to facilitate the process of flow into public education as well. But, literature also suggests, that it is not enough to use buzz technological tools, since even in schools with high levels of Web 2.0 use in the classroom there seems to be "little evidence of critical enquiry or analytical awareness, few examples of collaborative knowledge construction, and little publication or publishing outside of social networking sites" (Luckin et al., 2009). Transformations require a deeper intervention beyond simply making Web 2.0 technologies available, since a "fundamental problem lies in the cultural contradiction between institutional cultures that adopt conventional pedagogies and media cultures that leverage open and participatory spaces for collective participation" (Lim et al., 2010). The challenge 
is: how can tools designed for informal social interaction be integrated into the space of formal education, shift from content-centric to learner-centric model, appreciating interaction with others outside the community in terms of bringing in information, shifting the role of student to be knowledge builder, that of teacher to be co-learner and peers to learn in collaboration, yet facilitating individual assessment. It is indeed a challenge for teachers and they do need to participate in teacher communities to learn what others are doing, share ideas and practices before making their own transformations (Lim et al., 2010).

\section{Framework for Evaluating Digital Activities}

Benjamin Bloom classified learning objectives within education into a Taxonomy (Bloom, 1956) considering traditional classroom practices, behaviors and actions, which was later revised by using verbs rather than nouns for categories and exchanging Evaluating with Creating to be higher in order (Anderson and Krathwohl, 2001) compared to SOLO Taxonomy, which declared Extended Abstract level to be the highest, where the student is able to make connections not only with the given subject area, but also beyond it, as a Gestalt insight (Biggs and Collis, 1982). Only recently did new modifications come to light, to account for the new processes and actions to facilitate learning that is associated with Web 2.0 technologies and even producing the Digital Age Learning Matrix using more practice oriented verbs for categories: Doing; Thinking about connections; (combining Apply and Analyze into one category) Thinking about Concepts; Critiquing and evaluating; Creating Knowledge and Sharing Knowledge (Starkey, 2011). The author adapted the above for a more comprehensive interpretation within teacher training, emphasizing Applying as a vital category and considering Sharing to be on a higher level over Evaluation, appearing on the public stage and thus the slight modifications to distinguish between group sharing and public sharing (Fig. 3).

From the nature of the verbs used, it is evident that the learner is indeed actively doing something, is being engaged with the learning material, connecting new knowledge chunks with a previously mastered and well established knowledge base, applying the newly encountered connections to transferable areas, conceptualizing experiences and evaluating the outcomes to be able to contribute wisely to the collaborative knowledge building process within the learning group. And at a higher level sharing the built knowledge openly with a wider community in a social network, from which a more global feedback can be obtained, with new chunks of knowledge aggregated (gathered in a personalized manner) in order to further improve the quality of emerging knowledge.

The Technological Pedagogical and Content Knowledge (TPACK) model (Mishra and Koehler, 2006) defining the sorts of knowledge and skills that teachers require in order to implement technology-based learning designs successfully and emphasize the importance of the intersections between Technological Knowledge, Pedagogical Knowledge and Content Knowledge, and propose that effective integration of Web 2.0 technology into the curriculum requires a sensitive understanding of the dynamic relationship between all three components, pointing out the nature of the learning design as being more 


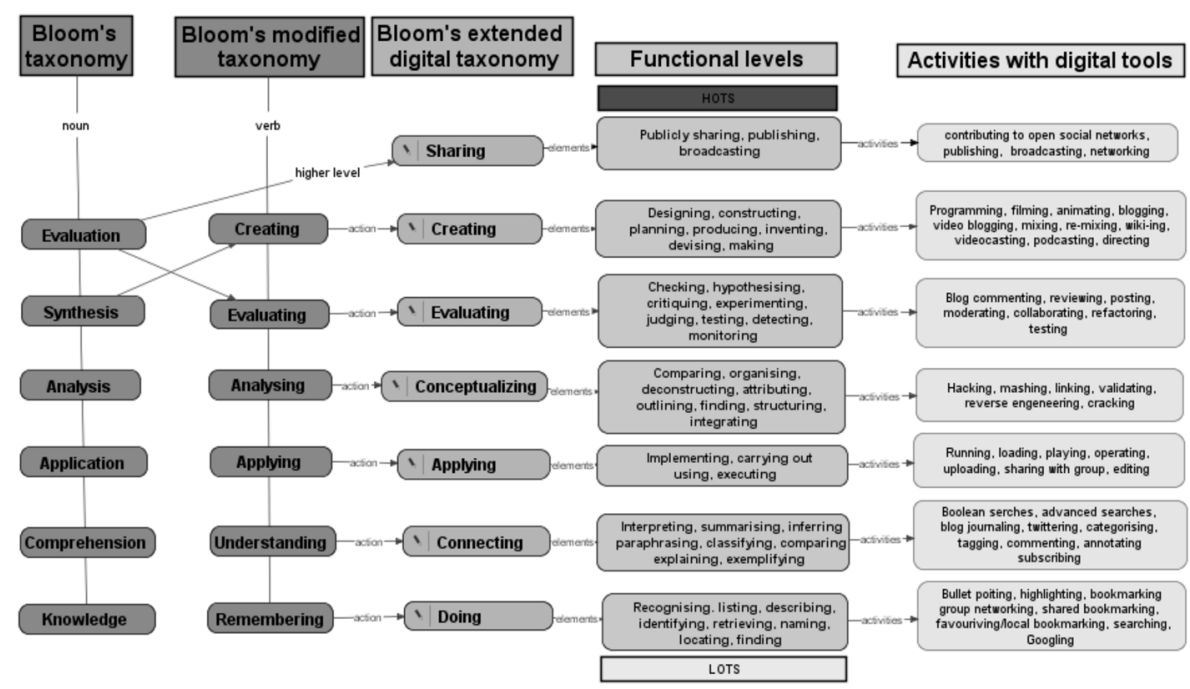

Fig. 3. Boom's Extended Digital Taxonomy as adapted by the author.

transmissive (T), dialogic (D), constructionist (C) or co-constructive (CC) (Bower et al., 2010). One of the new elements that has to be well considered while utilizing Web 2.0 tools is the ability of creating one's own Personal Learning Network (PLN), applying methodologies based in social networks from Constructionism to Connectivism. This lies within the highest level as "Sharing” within Bloom's Extended Digital Taxonomy, and resides outside the scope of a traditional classroom, it is very difficult to fit into a custom semester's timing and needs the luxury of relevance to one's own aims as opposed to compulsory tasks initiated by classroom activities. Thus, this kind of activity needs to be initiated as a continuum for the aftermath of the specific course and has to lead into the everyday professional practice within an active Community of Practice (CoP) (Lave and Wenger, 1991).

\section{Case Study: Teacher Education Program at ELTE}

At ELTE University general teacher education programs are being renewed and mostly taught by younger staff belonging to the Net generation or early adapters, so they themselves are aware of the needs and present life-style of learners and can motivate them more easily to adapt to new tools and methodologies. In bachelor as well as master level teacher training programs students have the option of selecting one of the offered 2 credit single semester courses ( 2 hours of lecture + lab activity per week) that tackles the theme of Modern Tools in Pedagogy. This means that there is very little time and space indeed to get acquainted with the above mentioned notions, not least to develop stable competencies in these areas. Thus the courses are toppled by introducing students to a newly developed CoP, the T@T Mentoring Network. 


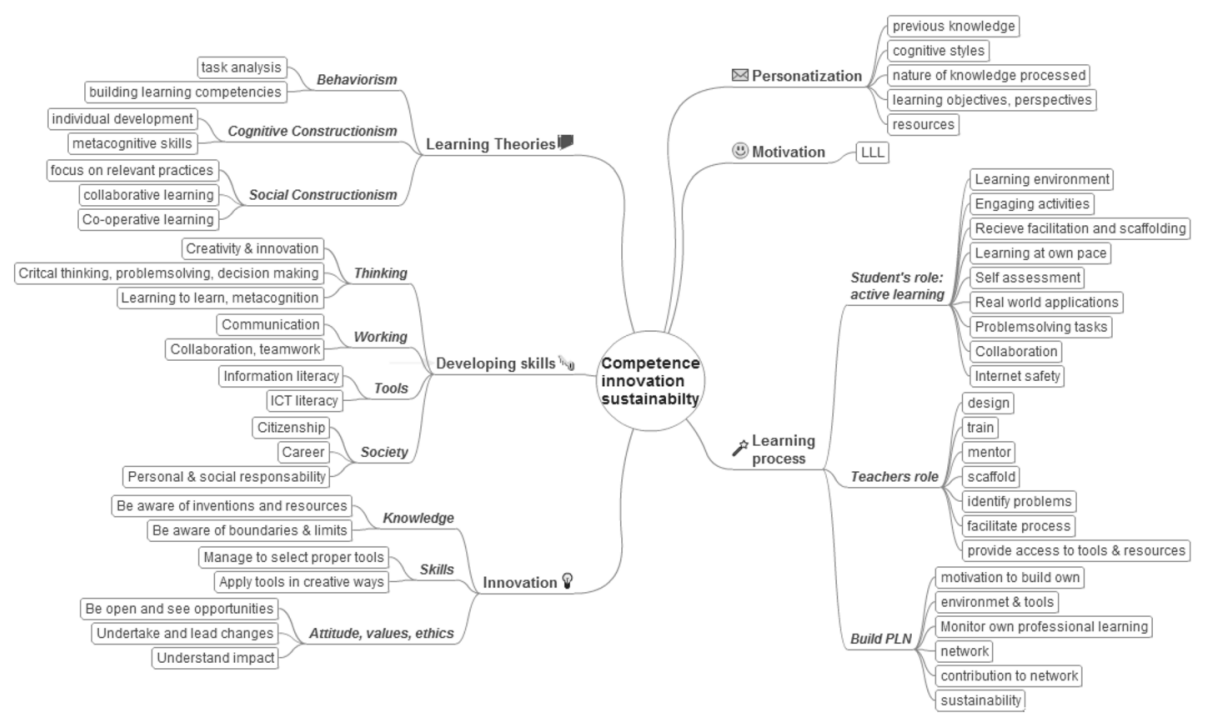

Fig. 4. Mindmap of aim's in teacher training, mirrored in course structure and in activities. http://matchsz.inf.elte.hu/TT/freemind/cel/cis_en.html.

Aims. One of the courses offered for either bachelor or master students (taught by the author, who is the head of T@T Lab) "Learning Technologies" attempts not just to teach about learning technologies and their adaptation within the learning processes, but also to lead students to become active members in knowledge building within a larger learning community $(\mathrm{CoP})$, adding their own values to enrich the outcomes and be able to communicate through different disciplines. In doing so, they must be able to choose from activities that are engaging, have adequate motivation to learn themselves, understand well the process and depth of learning and how suitable environments can be built for different learners, what role the teacher has in this environment, and how he/she can continuously build and renew his/her own PLN. Thus future teachers have to be aware of how they can adapt learning theories (from Behaviourism to Social Constructionism ) in practice, facilitate the development of skills in several areas (thinking, working, tools, and society responsibilities), and be aware of how innovation could be attained throughout their teaching practice by acquiring the necessary knowledge, skills, attitudes, values and ethics (Fig. 4). These are all key competences that are crucial in giving a meaning to the use of Web 2.0 technologies as Learning Technologies and verifying their pedagogical aims through Bloom's Extended Digital Taxonomy. The continuum within CoP provides the sustainability of innovative practice (which after developing a stable background for future teachers) ables the practicing teacher to transfer such competencies into public education.

The structure and process of the course had to make sure that these aims are met as much as possible, so the environment and tasks were built with respect to all the above considerations (http: / / matchsz. inf . elte.hu/TT/). 
Learning Management System (LMS). We used Edu2.0, establishing our own school (http: / / elteik.edu20.org/), which was localized by T@T Lab into Hungarian. This LMS allowed most of the valuable Web 2.0 functionality in a protected and safe environment with some excellent tools for knowledge building, making it possible to follow the progress of students and apply criteria based assessment. In fact Edu 2.0 was chosen as an example LMS that teachers could immediately use to set up for their own, even if they have no server capacity at school, since it is a hosted application. By using this tool for their own management and evaluation, student teachers learned the features from their own experiences and were able to apply and configure it to their own needs in setting up learning environments and assessment criteria.

Presentation Platform. An interactive whiteboard was used in class, the brand of which was irrelevant, since the course session just went lightly over the built-in functionality, but rather stressed the collaborative and interactive nature of group or whole-class activities that could be initiated by the help of any such whiteboard. Here, we emphasized on a whole inventory of highly interactive learning tools and general tools (http://www.delicious.com/tag/tethalo) that could be used for engaging collaborative whole class activities in form of experimentation, explorative learning and construction within different areas of discipline. Students also got acquainted with some game design tools that did not need programming skills, but provided high possibility in configuring games for specific needs.

Visual Understanding Environment (VUE) was localized by T@T Lab into Hungarian adding teacher training materials (http://matchsz.inf.elte.hu/VUE/) which was introduced as a mindmapping tool to make connections between chunks of knew knowledge to that of basic understanding. The tool could be mastered at basic level within two minutes, but lots of further tutorials and videos were provided to enhance sophisticated use, as a non-compulsory extension of course work. Indeed most of the tools introduced were just introduced on a basic level, providing further tutorials for deeper understanding, the use of which depended on students motivation whether they wished to master it at a higher level. VUE was highly valued by students for its low threshold and high ceiling, it being also a tool for processing ontologies as well as a sophisticated presentation tool.

Resources. Authoring tools were chosen based upon the scarce technical and budgetary situation of schools in general. Thus only free technology was listed and tools were being re-evaluated and updated each semester (http://www . pearl trees. com/tetlab). Evaluation of the use of tools was of great importance, as the value is not in the types and number of Web 2.0 tools used, but in the educational potential of the learning theory or pedagogic methodology they are being utalised. Thus, analyzing the theory behind mere functionality of each tool got a lot of emphasis. The "Bloom's Extended Digital Taxonomy" was used to verify the levels of learning taking place within a designed learning tasks (Fig. 3). Students also had to follow the emerging Technology Enhanced Learning tools appearing day by day (http://www.scoop.it/t/etel), and make sure that they are aware of the pace of change and develop continuous motivation in following innovation (http: / / twitter.com/Tetlab). 
Digital Narratives. As storytelling is one of the most effective introductory method in any theme or discipline, strong emphasis was given in introducing different tools and forms of media for developing digital narratives and illustrating the difference in potential for presenting. Thus, a good background of Media Literacy was also provided for future teachers to be able to understand media accessed through the net and be able to transfer that learned into effective presentation within their own disciplines and its effect in society (UNESCO, 2011). Every student had to create a final presentation of their own chosen theme and submit a written essay for others to understand the topic without further background readings.

Language Issues. Most of the students had problems with English language, so we pinpointed useful readings within a Diigo group and provided a lot of research tools, translations of terms within Technology Enhanced Learning topics, language tools and learning services to encourage them in improving their competencies with the English language (http://matchsz.inf.elte.hu/TT/link.html).

Student Community. Students from different disciplines, backgrounds and levels of education were accepted to learn together in the course semester. The broad spectrum of students was not least a boundary for progress, but indeed a very valuable virtue for the working group. Each student teacher could choose requirements according to abilities and topics of interest (increasing their level of motivation), process materials according to learning styles or preferences. Informatics teachers were not good at reading especially English literature, while they provided know-how in knowledge of technology and especially authoring tools and offered help to their peers. BA an MA students were happier to do the reading parts and asked for help with technology, while the other Science majors preferred deeper investigation into interactive tools in specific areas and relied on both sides for broadening their own knowledge. Class consultations and presentations on each chosen theme, in-class reactions as well as on-line feedbacks to each other's blog posts, knowledge building on Wiki allowed insight to all students into the broad picture and made them realize their own potential in the Vygotskian Zone of Proximal Development mechanism in broadening each others' levels of competencies (Vygotsky, 1978).

Cognitive Styles. A successful learning process demands that teaching methods respect learning differences. Cognitive styles are one of several important factors to be considered by designers of e-learning courseware (Béres and Turcsányi-Szabó, 2010). Apart from learning about the different models (Fig. 5), students could take a test in determining their own Learning Style and discuss in class their relevances in personalization, learning to learn, as well as understand why it is important to provide different kinds of alternative tasks for learners.

Collaborative Knowledge Building was one of the most difficult aims of the course. Wikis were rather used as "divide and concur", so the only task that allowed a natural and acceptable form of collaborative knowledge building was the use of collaborative mindmapping. Mind42 was chosen for this purpose towards the end of the semester and students were asked to insert items to include within a PLN 


\section{Learning Style Models}

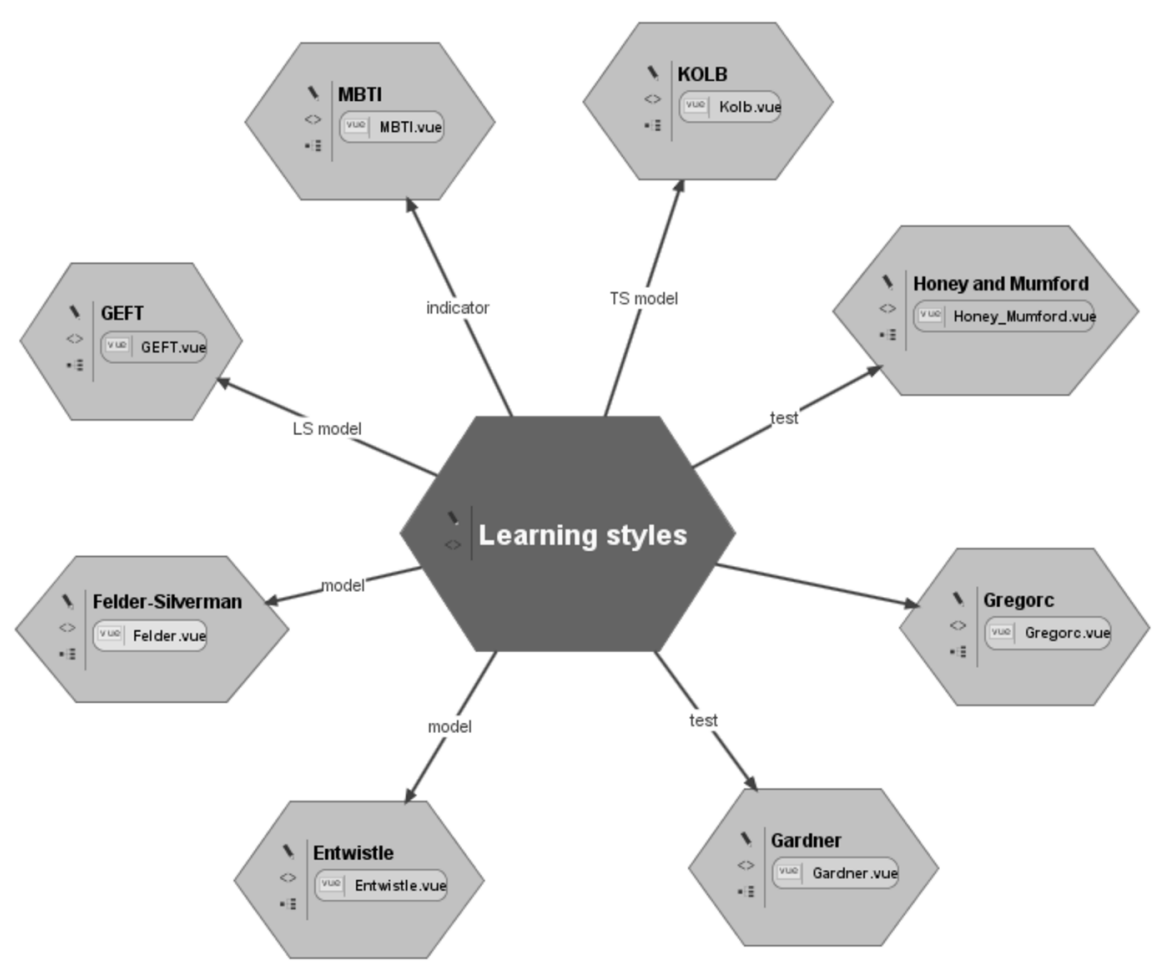

Fig. 5. Learning Style models and explanations as adapted in VUE (Béres and Turcsányi-Szabó, 2010) in Hungarian. http: //matchsz.inf.elte.hu/TT/TS/TS.html.

(http: //mind42. com/pub/mindmap?mid=85a51df7-47c1-4876-bc695 f20cd6daad6).

Building a PLN. One of the main aims of the course was to able students in building their own Personal Learning Network, by understanding the networking significance of cloud applications and their own social responsibilities, being able to follow innovation and select tools with critical mind, develop skills for filtering and aggregating data according to own needs, and not least "care to share". They had to blog weekly, providing logs for the teacher trainer and peers showing their own progress, use Twitter in aggregating and publishing their own "Aha" experiences. Features of Delicious, iGoogle and RSS feeds had to be mastered not only on reader level, but also on provider level, as they experienced how an individual's contribution can enhance a network's services (http: //www.netvibes.com/tet_labor/).

The Role of the Teacher. Each course session began with a short oral presentation by the teacher trainer on the relevance of each topics, narratives of case studies were used to illustrate their indispensible values. After that, the teacher trainer consulted with each student to provide guidance with chosen topic and orientation for choosing resources to 
achieve aimed tasks. During that time, one of the students with informatics major presented a hands-on session for start-out in use of a selected tool, after which students were guided to a Wiki page, which provides platform for explanations on notions of Technology Enhanced Learning and provides "How-to" tutorials to enrich the background knowledge of those interested (http://szasza.elte.hu/).

\section{Requirements for Students in Different Disciplines and Levels of Study}

\section{Informatics Future Teacher}

1. Choose three unprocessed tools within the inventory of tool descriptions (http:// szasza.elte.hu/) and create their descriptions according to the given templates. $(C-25$ pts $)$. [Apart from this short tutorial in Hungarian being useful for teachers and students (not knowing English) to start out activities, the student teacher could contribute to public education by inserting it into the Wiki space.]

2. Assemble a relevant set of tools using one of these frames (VUE, Symbaloo, Livebinders or Prezi) to aid a specific topic of a discipline. $(T-20 \mathrm{pts})$.

3. Write a weekly blog on your impressions while working on your assignments and on encountered tools and course experiences as well as take active and collaborative role in real and virtual group-work (e.g., read and comment on others' blogs, advise resources if relevant, ask questions for clarification ... etc. $(D-15 \mathrm{pts})$. [The first Blog should start out with expectation from this course and could suggest topics to be tackled in class. The teacher trainer comments on blogs and provides personalized orientation for specific trails advised. Peers also read each others' blogs and give feed-back, while exchanging views on experiences.]

4. Insert all valuable tools encountered into Delicious adding "TeThalo" (network identifier) tag. $(C C-10 \mathrm{pts})$. [Apart from sharing valuable bookmarks within class, this is also a contribution to the social network.]

5. Evaluate the work of others. $(D-15 \mathrm{pts})$.

6. Add your own input to the collaborative Mind42 mindmap on the actual theme of the semester. $(C C-10 \mathrm{pts})$. [Collaborative knowledge building assignment that develops throughout the second part of the semester and produces a map to be shared in the teachers' social network.]

7. Join T@T Mentoring Network (http://tet-halo.ning.com/). (CC $5 \mathrm{pts}$ ). [Presumably, they have learned a lot from other's contributions and they have by now also made their own contributions and thus got a taste of being an active member of a professional social network, which might result in their persistent activity within that Community of Practice.

\section{Differences for Other BSc or BA Future Teacher}

1. Choose a social networking tool and create a learning circle on a specified theme, choosing at least one of each tool (interactive learning tool, authoring tool, game design tool) with assessment strategy inviting at least two peers for review. ( $C$ $-25 \mathrm{pts}$ ). [Setting up a learning circle, curricula with assessment is one of the everyday duties of teachers.] 
2. Create the complete course structure (from pre-made resources) using one of the following frame: VUE, Prezi, Symbaloo. $(T-20 \mathrm{pts})$. [This assignment requires only links and hierarchical constructions of learning materials.]

\section{Differences for Other MSc or MA Future Teacher}

1. Choose one of the themes from emerging TEL tools (http: / /www. scoop.it/ $t / e t e l)$, do some research within further literature and analyze the readings to produce a short synthesis in the Wiki area for others to understand. $(C-$ $25 \mathrm{pts}$ ). [Since all literature is in English and not all students are able to understand it, this summary should be concise enough to allow full understanding for peers. Students undertaking this assignment should also find connections between their own writings and that of others and make the connections relevant by linking.]

2. Prepare a presentation on your theme for the next generation of students, using one of the following authoring tool: VUE, Prezi, video podcast. ( $T$ $20 \mathrm{pts}$ ). [Presentations will become a good introduction for the next semester for students to foresee their duties and are also shared in the teacher's network.]

Letters indicate the nature of the learning design (see end of Section 2) and show that all students are required to be active in constructionist and transitive activities in accordance with their profile and take part equally in several dialigic and co-constructive activities. Pts indicated attainable points resulting in a total of 100 , the percentage of which attained provides the resulting grade.

It is quite obvious that a single course is not enough for accomplishing desired goals. Thus, further needs for mentoring is quite obvious, so the course is toppled by introducing students to a newly developed CoP, the T@T Mentoring Network (http: / tethalo.ning.com/).

\section{T@T Mentoring Network}

The T@T (indicating Technology Enhanced Learning in Hungraian) Mentoring Network has just been set up by T@T lab http: / / tet.inf.elte.hu/(headed by the author) to provide help and guidance for future teachers, practicing teachers and those starting to adapt to new tools and methodologies within the whole range of the education system. The lab is devoted to $R \& D$ for emerging learning tools and is presently active with several related developments (http://matchsz.inf.elte.hu/VVprojekt/).

Putting the learners into the middle of the process and orienting them into learning possibilities that develop their own needs, raising required competencies, becoming autonomous learners, providing access to knowledge on demand and keeping their motivation alert to accommodate changes is the main aim of the network. A Web 2.0 supported Ning community portal lies at the heart of the network that provides connectivity http://tet-halo.ning.com/ and is operated in collaboration between T@T Lab and John von Neumann Computer Society Public Education SIG. The network tries to reach practicing teachers through its FaceBook page 


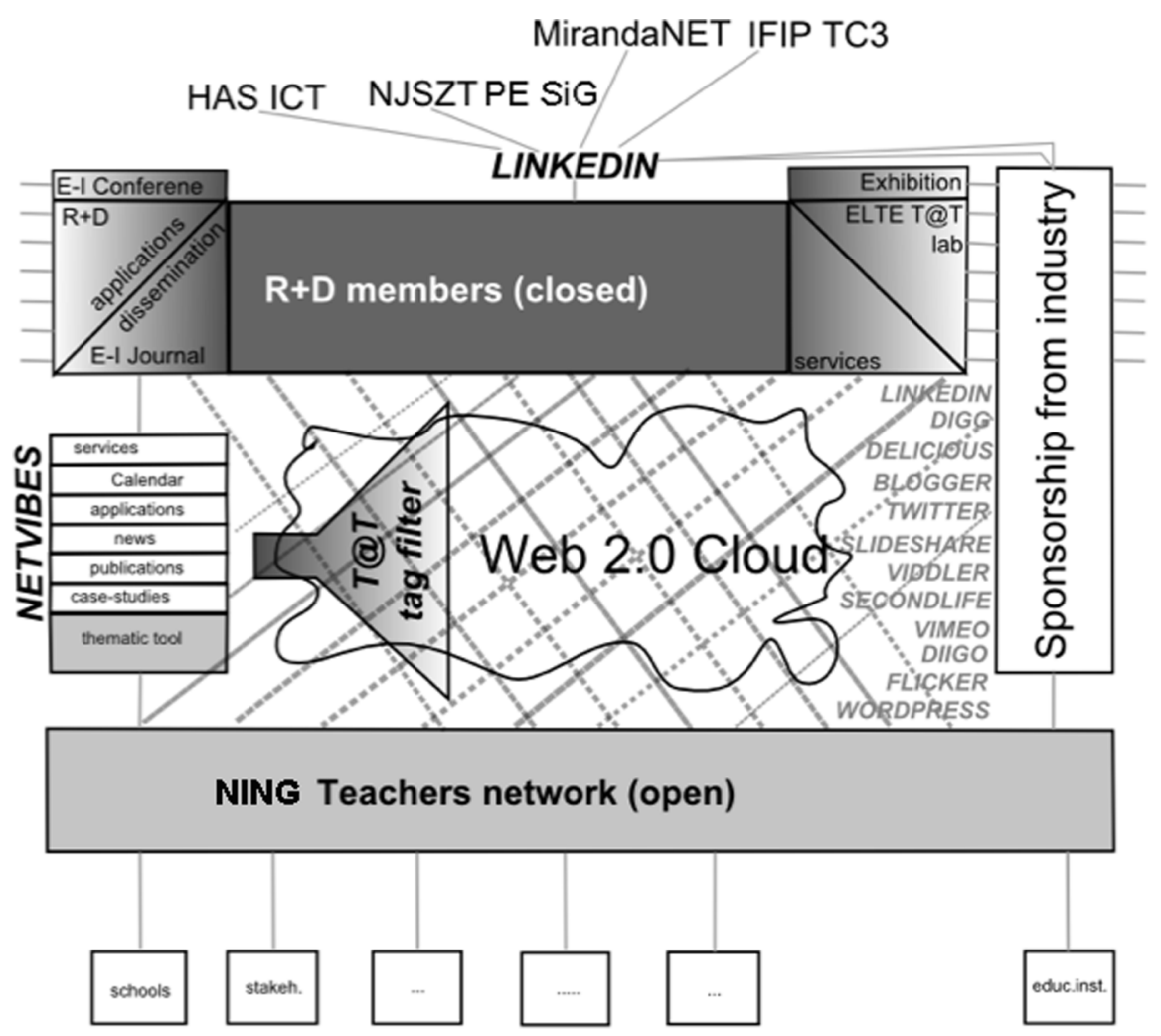

Fig. 6. Structure of T@T Mentoring Network (in Prezi). http://prezi.com/dict1whnts4e/tt-network/.

(http: / / www . facebook. com/pages / TT-h\%C3\%A11\%C3\%B3/2424990657 62421 ) in which most of the practicing teachers are quite active. The mentoring portal is open to any person involved in education, researcher or developer who has registered giving proper credentials (LinkedIn, FaceBook, or institutional web page) to take active part in this "all win" community.

Members of the T@T Mentoring Network (future teachers, practicing teachers, teacher trainers, researchers, stake holders, etc.) can keep up with their normal every day use of Web 2.0 technologies (Tweet, Blog, share bookmarks on Delicious, ... etc.), they just have to make sure that they also use the tag "TeThalo" if they wish to share an item within the mentoring network. All items tagged as such and within the agreed Web 2.0 inventory are aggregated into the Netvibes pages http: / / www . netvibes.com/tet_labor to enrich the resources of the community, resulting in a sustainable flow of innovative ideas and resources that can be further used within teacher training. The Netvibes pages contains 4 main pages: describing the purpose of the network through presentations, providing relevant news feeds in English and another page restricted to Hungarian news feeds, a collection of tools for research $\&$ information retrievel, and a page that contains specific tools and links promoted by 


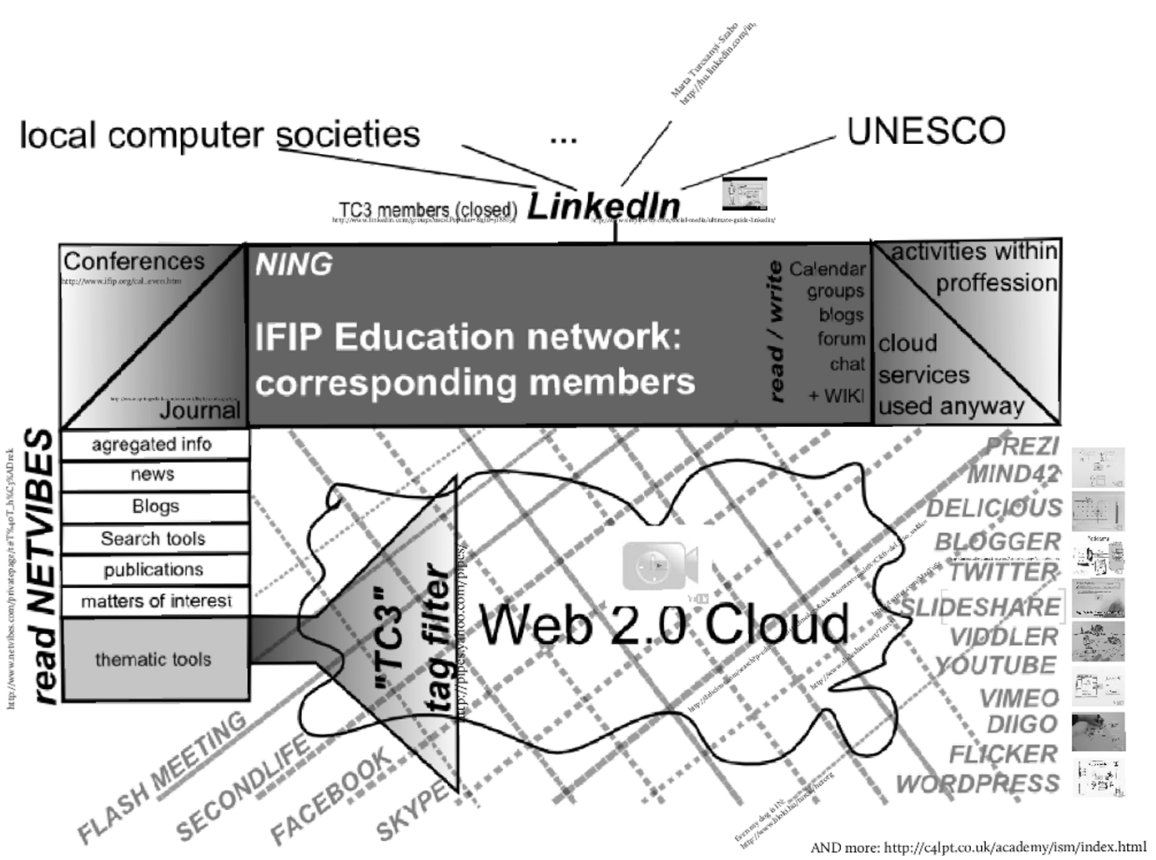

Fig. 7. Structure of IFIP Education Network (in Prezi).

http://prezi.com/18v09u_ckg77/ifip-tc3-network/.

T@T Lab itself. The Netvibes pages can also be used as a start-out page in a browser and individuals can add further pages for personal use.

Collaboration has been established between Faculties at ELTE University, doing research together on topics concerning innovation in learning (using http://bscw. elte.hu/ as closed network) and inviting other university professionals as well as industry professionals related to emerging educational tools to join the network and take part in dissemination of innovation for continuous sustainability. All Faculties at ELTE have developed and constantly update their innovative recourses and share them with each other within the full spectrum of teacher training as well as reach out to help newly released teachers entering their profession at school and practicing teachers already in service. Yearly conferences are being held and a new Journal was issued on Educational Technology (Oktatás-Informatika) by ELTE University Faculty of Education and Psychology.

The process is monitored and further disruptions are negotiated inside the T@T Network of local teacher trainers, researchers, developers forum within LinkedIn (http: / /www. linkedin.com/), that also share the portfolios of academic partners in the country, which provides backgrounds in establishing new projects both locally and internationally as well as publish research findings in local and international circles. 
The structure of the T@T Mentoring Network (Fig. 6) is very similar to the structure of the IFIP Education Network (Fig .7, both administered by the author), allowing local teachers (after having adequate confidence with language) to swim over to international grounds and take part in CoP using English language, to become part of the global community.

\section{Conclusion}

Although everyone is experiencing the vast speed on innovation in technology and teacher education and is well aware that significant changes are needed to take place in teacher training in order to cope with challenges of present times and to be able to live up to expectations in bringing up a next generation with adequate competencies for living and working in the 21st century, yet a lot of efforts are just accomplished by ticking out buzz words that essentially do not lead to significant changes. Changes can only take place if the heart of innovation lies within the pedagogic approach in utilization of modern tools, which takes into consideration the changing features in tendencies shaping Information and Communication Technologies, media and the emerging need for active participation of individuals within communities.

The framework for developing learning design must originate from the tendencies in the development of Web technologies that influence the way we work and live an active life in media, transferring the tendencies to become an affordance in the teaching/learning process, which truly changes the role of the teacher and provides personalized learning facilities for active learners.

Bloom's Extended Digital Taxonomy has been explained as the basis for evaluating the use of tools in the learning process, which has to be implemented with care into teacher training in order to enhance the Technological Pedagogical and Content Knowledge of teachers. The efforts made at ELTE University were shown with a case study of a single course on Educational Technology, showing its complex aims, methodology and resources used, description on how the nature of the learning design in the course requirements contributes to the adaptation of theory into practice. The role of a newly established T@T Mentoring Network is explained, to further develop competencies in digital literacy and modern teaching/learning methodologies, presuming it would also provide sustainability in innovation within teacher training and the network of in-service and practicing teachers.

Although at an early stage, we have experiences of good practices, a critical mass of continuously increasing younger generation of educators and our good will to make this project succeed and flourish for the benefit of the next generation.

Acknowledgement. The Project is supported by the European Union and co-financed by the European Social Fund (grant agreement No. TÁMOP-4.1.2-08/2/B/KMR-20090002). 


\section{References}

Anderson, L.W., Krathwohl, D.R. (Eds.) (2001). A Taxonomy for Learning, Teaching, and Assessing: A Revision of Bloom's Taxonomy of Educational Objectives. New York, Longman.

Anderson, P. (2007). What is Web 2.0? Ideas, technologies and implications for education, JISC Technology \& Standards Watch. Tech. Watch Report.

http: / / www.jisc.ac.uk/publications/reports/2007/twweb2 .aspx.

Béres, I., Turcsányi-Szabó, M. (2010). Added value model of collaboration in higher education. Interdisciplinary Journal of E-Learning and Learning Objects, 6, 205-215. http: / / www. ijello.org/Volume6/IJELLOv6p203-215Beres723.pdf.

Biggs, J., Collis, K. (1982). Evaluating the Quality of Learning: The SOLO Taxonomy. New York, Academic Press.

Bloom, B. (Ed.) (1956). Taxonomy of Educational Objectives: The Classification of Educational Goals. pp. 201-207, Susan Fauer Company, Inc.

Bower, M., Hedberg, J.G., Kuswara, A. (2010). A framework for Web 2.0 learning design. Educational Media International, 47(3), 177-198.

Brown, S. (2008). From VLEs to learning webs: the implications of Web 2.0 for learning and teaching. Interactive Learning Environments, 18(1), 1-10.

Corrin, L., Lockyer, L., Bennett, S. (2010). Technological diversity: an investigation of students' technology use in everyday life and academic study. Learning, Media and Technology, 35(4), 387-401.

Lave, Jean, Wenger, Etienne (1991). Situated Learning: Legitimate Peripheral Participation. Cambridge, Cambridge University Press.

Lim, W., So, H., Tan, S. (2010). eLearning 2.0 and new literacies: are social practices lagging behind? Interactive Learning Environments, 18(3), 203-218.

Luckin, R., Clark, W., Logan, K., Graber, R., Oliver, M., Mee, A. (2009). Do web 2.0 tools really open the door to learning: practices, perceptions and profiles of 11-16 year olds learners. Learning, Media and Technology, 34(2), 87-114.

Mishra, P., Koehler, M.J. (2006). Technological pedagogical content knowledge: A framework for teacher knowledge. Teachers College Record, 108(6), 1017-1054.

OECD (2009). Creating Effective Teaching and Learning Environments: First Results from TALIS, 26-28. http: / / www . oecd.org/edu/talis/firstresults.

Sir Ken Robinson (2011). Changing Paradigms in Education, TED Talk. http: //sirkenrobinson.com/skr/category/education.

Starkey, L. (2011). Evaluating learning in the 21st century: a digital age learning matrix. Technology, Pedagogy and Education, 20(1), 19-39.

Tapscott, D. (2009). Grown up Digital: How the Net Generation is Changing Your World. New York, McGrawHill.

Tiropanis, Th., Davis, H., Millard, D., Weal, M., White, S., Wills, G. (2009). Semantic technologies in learning and teaching. JISC - SemTech Project Report. http: //www.jisc.ac.uk/publications/reports/2009/semantictechnologiesre port. aspx.

UNESCO (2011). Media and Information Literacy Curriculum for Teachers. http: / / portal.unesco.org/ci/en/ev.php-URL_ID=31461\&URL_DO=DO_TOPIC\&URL_ SECTION=201.html.

Vygotsky, L.S., (1978). Mind in Society. Cambridge, MA, Harvard University Press.

Walsh, K. (2011). Do Popular Social Networking Applications Have A Place in the Classroom? A Growing Number of Educators Say 'Yes'. EmergingEdteck.

http: / / www . emergingedtech.com/2011/03/facebook-in-the-classroom-

seriously/. 
M. Turcsányi-Szabó is an associate professor, head of ELTE T@T Lab http: / / tet . inf.elte.hu (formerly TeaM lab), Department of Media \& Educational Technology at Eötvös Loránd University, Faculty of Informatics in Hungary.

With more than 25 years in teacher education she is now specialised in courses: Educational technology \& Social Networking, Tele-mentoring, Authoring environments for children, Evaluating educational programs, Designing educational programs, Designing multimedia materials for B,Sc. \& M.Sc. level as well as Research methodology, Innovative capacity building digital pedagogy, Current issues of e-Learning, Theoretical basis of ICT education for PhD level.

Her research area is Technology Enhanced Learning and now concentrates on Media Informatics. Her most remarkable projects were: developing software for kindergarten children continuously since 1984; developing a model for Tele-houses, mentoring youth living in underdeveloped regions and providing them a perspective for their future; developing TeaM Challenge game series, that provides context based "e-problem solving" and team work, through interdisciplinary topics in upper elementary; building several mentoring models for practical teacher training, producing the basis for the needs of teachers/mentors and transferring innovation into public education by meeting the notion and requirements of the present age.

\section{Atsinaujinančiu inovaciju siekimas mokytoju rengime - nuo teorijos prie praktikos}

\section{Márta TURCSÁNYI-SZABÓ}

Straipsnyje aprašoma mokymosi projektavimo sistema, naudojant antros kartos saityno technologijas mokytoju rengime. Norima padidinti mokytoju technologines pedagogines ir turinio žinias.

Pasinaudojus atvejo analizès metodu, parodoma, kaip Budapešto Eötvös Loránd universitetas bando plètoti kompetenciju atnaujinimo naujoves skaitmeniniame raštingume ir šiuolaikinèse mokymo/mokymosi metodikose tiesiogiai mokytoju rengime tarp dėstytojų, bei netiesiogiai per visuomenès švietimą, siekiant perduoti naujoves ten.

Sudètinių tikslų turintis specialus kursas „Educational Technology“ yra aprašomas su išsamiais metodologiniais paaiškinimais, duodamos nuorodos ị konkrečias priemones ir naudojamus išteklius. 